\title{
Analisis Kesalahan Penggunaan Tanda Baca dalam Karangan Peserta Didik
}

\author{
Andi Hasrianti \\ UIN Alauddin \\ andi.hasrianti@uin-alauddin.ac.id
}

\begin{abstract}
Abstrak
Penelitian ini merupakan penelitian kualitatif deskriptif yang bertujuan untuk mendapatkan gambaran mengenai kesalahan-kesalahan dalam menggunakan tanda baca pada tulisan karangan peserta didik kelas V MIN 2 Takalar. Sumber data dalam penelitian ini adalah guru dan peserta didik kelas V MIN 2 Takalar yang berjumlah 6 orang. Data dikumpulkan melalui tes, tugas, dan wawancara berbasis tugas. Hasil penelitian menunjukkan bahwa kesalahan penggunaan tanda koma adalah hal yang paling sering dilakukan oleh peserta didik. Penyebabnya adalah kesalahan penggunaan tanda koma yaitu peserta didik tidak menggunakan tanda koma di antara unsur-unsur dalam suatu pemerincian, untuk mengapit keterangan tambahan, dan untuk menghindari salah baca di belakang keterangan yang terdapat pada awal kalimat. Kesalahan penggunaan tanda titik sering terjadi karena peserta didik tidak memberi tanda titik pada akhir kalimat yang bukan pertanyaan atau seruan. Kesalahan penggunaan tanda hubung disebabkan karena tidak menggunakan tanda hubung untuk menandai bagian kata yang terpenggal oleh pergantian baris dan tidak menggunakan tanda hubung untuk menyambung unsur kata ulang. Adapun kesalahan penggunaan tanda titik koma karena peserta didik tidak menggunakannya sebagai pengganti kata hubung untuk memisahkan kalimat setara yang satu dari kalimat setara yang lainnya dalam kalimat majemuk. Hasil penelitian ini penting buat peserta didik untuk meningkatkan rasa ingin tahu mengenai ejaan karena berkaitan dengan kehidupan sehari-hari, terutama ketika menulis.
\end{abstract}

Kata kunci: analisis kesalahan, tanda baca, karangan.

\section{Pendahuluan}

Pembelajaran Bahasa Indonesia dalam dunia pendidikan meliputi empat aspek yang harus dikuasai oleh peserta didik, yaitu: membaca, menyimak, berbicara, dan menulis. Salah satu keterampilan berbahasa yang harus dimiliki oleh peserta didik adalah keterampilan menulis karena menulis merupakan suatu kegiatan yang produktif dan ekspresif. Jadi, dengan menulis seseorang dapat mengungkapkan atau mengekspresikan diri dan perasaannya melalui suatu karya atau produk yang disebut tulisan (Kuspitasari, 2013:1).

Menulis sebagai suatu keterampilan dalam berbahasa adalah suatu kegiatan penyampaian pesan dengan menggunakan bahasa tulis sebagai medianya. Pesan adalah isi yang terkandung dalam sebuah tulisan, di mana tulisan merupakan sebuah simbol atau lambang yang dapat dilihat dan disepakati pemakaiannya. Berkomunikasi menggunakan bahasa tulis paling tidak terdapat 4 unsur yang terlibat yaitu: penulis sebagai penyampai atau pemberi pesan; isi tulisan sebagai hal yang disampaikan; saluran atau media dalam menyampaikan pesan; pembaca sebagai penerima pesan (Puspitasari, 2014:1)

Salah satu aspek keterampilan berbahasa yang berkaitan dengan menulis, mengungkapkan ide, gagasan, pikiran, pendapat, dan perasaan adalah keterampilan dalam 
menulis karangan. Karangan adalah hasil perwujudan gagasan atau ide seseorang yang dituangkan dalam bahasa tulis dan mempunyai tujuan tertentu, baik itu memberikan informasi, menggambarkan keadaan, memaparkan sesuatu, ataupun berupa ajakan. Adapun ciri-ciri karangan yang baik yaitu (1) mudah diterima dan dipahami oleh pembaca, (2) kalimat penjelasnya logis, (3) setiap kalimat tersusun dengan urut dan logis, serta (4) efisien dan ekonomis agar pembaca mudah menangkap atau memahami isi karangan.

Ada beberapa jenis karangan berdasarkan bentuk dan tujuan penulisannya, yaitu karangan narasi, karangan deskripsi, karangan eksposisi, karangan argumentasi, dan karangan persuasi. Salah satu materi yang terdapat tugas peserta didik untuk membuat karangan yaitu pada materi kelas 5 SD dalam tema 5 sub tema 2 pembelajaran 4 . Materi pada pembelajaran ini berupa penjelasan dan contoh mengenai ketampakan alam yaitu Gunung Sinabung yang terletak di Sumatera Utara dan ketampakan buatan yaitu kebun teh yang berada di Puncak, Bogor. Setelah membaca teks bacaan yang berjudul "Indahnya Kebun Teh di Puncak, Bogor" peserta didik diberi tugas untuk membuat pertanyaan berdasarkan bacaan yang telah dibaca kemudian diperiksa dengan cara bertukar dengan teman sebangku. Tugas peserta didik pada pembelajaran ini tidak hanya membuat pertanyaan, tetapi peserta didik juga diberi tugas untuk berlatih membuat teks nonfiksi yaitu karangan tentang ketampakan alam di daerah sekitar, yaitu ketampakan alam di sekitar lingkungan sekolah (Karitas, 2013: 76-81).

Tugas membuat karangan diberikan kepada peserta didik untuk mengetahui pengalaman peserta didik, meningkatkan rasa ingin tahu peserta didik, serta melatih kemampuan peserta didik dalam menggunakan kosakata. Selain itu, peserta didik juga dilatih untuk mengingat kembali pengalaman yang pernah dilaluinya, kemampuan menggambarkan keadaan, serta dalam mengolah informasi yang dimilikinya. Dari hasil observasi terhadap hasil tulisan peserta didik kelas V MIN 2 Takalar ditemukan adanya keberagaman hasil karya peserta didik. Keberagaman tersebut terlihat adanya peserta didik yang masih salah dalam menggunakan huruf, kata, ataupun tanda baca. Mengingat pentingnya sebuah keterampilan menulis maka hendaknya pendidik senantiasa mengajar dan memotivasi peserta didik untuk belajar, meningkatkan rasa ingin tahu, serta minat peserta didik untuk menulis.

Berkomunikasi dengan menggunakan bahasa lisan berbeda dengan karakteristik bahasa tulis. Berkomunikasi menggunakan bahasa lisan akan lebih mudah dipahami oleh pendengar atau lawan bicara, hal ini dikarenakan adanya bantuan unsur-unsur nonlinguistik yang berupa intonasi, gerak-gerik tangan, gelengan kepala, dan sebagainya. Berbeda dalam bahasa tulis, seorang penulis harus mengetahui bahkan menguasai tata cara penulisan yang sesuai dengan kaidah yang telah ditentukan dalam PUEBI, salah satunya yaitu penggunaan tanda baca (RM, 2019:3)

Penggunaan tanda baca dalam sebuah tulisan dapat membantu pembaca untuk memahami pesan yang disampaikan oleh penulis. Dapat dibayangkan bila sebuah tulisan tidak menggunakan tanda baca, mungkin pembaca akan merasa bingung dan kesulitan karena tanda baca dalam sebuah tulisan itu berfungsi untuk membantu pembaca dalam memahami sebuah tulisan. Penggunaan tanda baca dalam tulisan juga digunakan agar pembaca tidak salah paham dalam memahami makna sebuah tulisan.

Dalam sebuah penulisan, sering kita jumpai kesalahan dalam penggunaan tanda titik (.), misalnya seseorang menulis kemudian tidak menggunakan tanda titik pada akhir 
kalimat sehingga pembaca menyambung antara kalimat yang satu dengan kalimat berikutnya. Selain itu penghilangan tanda titik juga tidak memberi jeda sewaktu membaca tulisan yang akan berakibat kesalahpahaman atau salah arti.

Selain kesalahan dalam penggunaan tanda titik, juga sering dijumpai kesalahan dalam penggunaan tanda tanya (?). Sering dijumpai sebuah tulisan yang menggunakan tanda tanya pada akhir sebuah pernyataan sehingga seolah-olah penulis itu bertanya padahal itu sebuah pernyataan yang bersifat informasi sehingga tidak memerlukan jawaban. Sebaliknya, juga sering dijumpai tulisan yang tidak menggunakan tanda tanya pada akhir kalimat tanya sehingga pembaca dapat salah paham dan bingung, apakah kalimat tersebut sebuah pertanyaan atau hanya sebuah pernyataan.

Selain kesalahan penggunaan tanda titik dan tanda tanya, ada beberapa kesalahankesalahan penggunaan tanda baca lainnya yang sering muncul dalam sebuah tulisan. Pedoman Umum Ejaan Bahasa Indonesia (PUEBI) terdap 15 tanda baca yang masingmasing mempunyai fungsi berdasarkan bentuknya masing-masing yaitu: tanda titik (.), tanda koma (), tanda titik koma (;), tanda titik dua (:), tanda hubung (-), tanda pisah (-), tanda elipsis (...), tanda tanya (?), tanda seru (!), tanda kurung ((..)), tanda kurung siku ([ ]), tanda petik ganda (“..."), tanda petik tunggal ( '), tanda garis miring (/), dan tanda penyingkat atau apostrof (') (Halimah, A, 2013:19).

Kesalahan penggunaan tanda baca disebabkan karena terkadang peserta didik maupun pendidik kurang memperhatikan penggunaan ejaan yang tepat, termasuk penggunaan tanda baca ketika menulis. Ketika menulis, cenderung pendidik dan peserta didik menganggap mudah atau tidak menghiraukan kesalahan-kesalahan seperti itu sehingga lama kelamaan menjadi terbiasa.

\section{Metode}

Penelitian ini adalah jenis penelitian kualitatif yang sifatnya deskriptif. Penelitian ini dilakukan di kelas V MIN 2 Takalar. Teknik pengumpulan data dimulai dengan memberikan tugas kepada siswa untuk menulis karangan dengan tema "Lingkungan Sekolah". Tujuannya adalah untuk melihat kemampuan menulis karangan peserta didik dalam menerapkan penggunaan tanda baca. Hasil dari tugas yang diberikan di analisa dan kemudian ditetapkan 5 hasil karangan sebagai subjek. Dipilih lima karangan dengan tujuan bahwa hasil karangan tersebut mewakili keseluruhan kesalahan-kesalahan yang terdapat pada tanda baca. Kemudian dilakukan wawancara mendalam kepada subjek terkait karangan yang dihasilkan. Selain wawancara dengan subjek dilakukan juga wawancara kepada wali kelas V MIN 2 Takalar terkait hasil tulisan karangan siswa. Ada delapan poin pertanyaan umum yang diajukan kepada guru, yaitu: 1) Tanda baca apa yang pernah diajarkan kepada peserta didik? 2) Metode apa yang digunakan dalam menyampaikan atau mengajarkan materi tanda baca? 3) Media apa yang digunakan dalam mengajarkan materi tanda baca? 4) Bagaimana pemahaman peserta didik tentang penggunaan tanda baca? 5) Apakah ada kendala yang dihadapi peserta didik dalam menggunakan tanda baca ketika menulis? 6) Kesalahan tanda baca apa yang paling sering dilakukan oleh peserta didik? 7) Apa yang menyebabkan peserta didik melakukan kesalahan penggunaan tanda baca ketika menulis? 8) Bagaimana solusi untuk mengatasi masalah di atas? Tujuannya yaitu untuk 
memproleh informasi mendalam terkait hasil karangan subjek. Teknik analisis data dalam penelitian ini yaitu reduksi data, penyajian data, dan penarikan kesimpulan.

\section{Hasil dan Pembahasan Hasil}

Gambaran hasil analisis karangan yang dibuat oleh subjek disajikan dalam bentuk deskripsi beserta alternatif perbaikannya yang akan diuraikan satu persatu pada Tabel di bawah ini:

Table 1. Hasil Analisis Karangan Subjek 01

\begin{tabular}{|c|c|c|c|c|}
\hline No. & $\begin{array}{c}\text { Kode } \\
\text { Kesalahan }\end{array}$ & Kalimat & Penjelasan Kesalahan & Alternatif Perbaikan \\
\hline 1 & KPTT & $\begin{array}{l}\text { Setiap hari saya } \\
\text { berjalan kaki dari } \\
\text { rumah ke sekolah. } \\
\text { Rumahku berjarak } \\
\text { sekitar 300-meter dari } \\
\text { sekolah. }\end{array}$ & $\begin{array}{l}\text { Menggunakan tanda } \\
\text { koma setelah kata } \\
\text { sekolah karena } \\
\text { kalimat selanjutnya } \\
\text { merupakan } \\
\text { keterangan tambahan } \\
\text { atau aposisi. }\end{array}$ & $\begin{array}{l}\text { Setiap hari saya } \\
\text { berjalan kaki dari } \\
\text { rumah ke sekolah, } \\
\text { rumahku berjarak } \\
\text { sekitar } 300 \text {-meter dari } \\
\text { sekolah. }\end{array}$ \\
\hline 2 & KPTK & $\begin{array}{l}\text { Di tengah-tengah ada } \\
\text { lapangan yang biasa } \\
\text { dilakukan upacara } \\
\text { bendera dan digunakan } \\
\text { sebagai tempat } \\
\text { olahraga, }\end{array}$ & $\begin{array}{l}\text { Menggunakan tanda } \\
\text { titik setelah kata } \\
\text { olahraga karena } \\
\text { merupakan akhir } \\
\text { kalimat pernyataan. }\end{array}$ & $\begin{array}{l}\text { Di tengah-tengah ada } \\
\text { lapangan yang biasa } \\
\text { dilakukan upacara } \\
\text { bendera dan } \\
\text { digunakan sebagai } \\
\text { tempat olahraga. }\end{array}$ \\
\hline 3 & KPTK & $\begin{array}{l}\text { Di sekolahku ada } \\
\text { banyak ruangan ruang } \\
\text { kelas, ruang kepala } \\
\text { sekolah, ruang guru, wc, } \\
\text { dan dapur sekolah. }\end{array}$ & $\begin{array}{l}\text { Menggunakan tanda } \\
\text { koma setelah kata } \\
\text { ruangan karena } \\
\text { adanya keterangan } \\
\text { tambahan pada } \\
\text { kalimat berikutnya. }\end{array}$ & $\begin{array}{l}\text { Di sekolahku ada } \\
\text { banyak ruangan, } \\
\text { ruang kelas, ruang } \\
\text { kepala sekolah, ruang } \\
\text { guru, wc, dan dapur } \\
\text { sekolah. }\end{array}$ \\
\hline 4 & $\begin{array}{l}\text { KPTK dan } \\
\text { KPTT }\end{array}$ & $\begin{array}{l}\text { Disamping kanan dan } \\
\text { kiri banyak rumah } \\
\text { warga-warga ada } \\
\text { rumah panggung dan } \\
\text { ada juga rumah batu }\end{array}$ & $\begin{array}{l}\text { Menggunakan tanda } \\
\text { koma setelah kata } \\
\text { warga-warga karena } \\
\text { adanya keterangan } \\
\text { tambahan dan tanda } \\
\text { titik setelah kata } \\
\text { rumah batu karena } \\
\text { akhir kalimat } \\
\text { pernyataan. }\end{array}$ & $\begin{array}{l}\text { Di samping kanan dan } \\
\text { kiri banyak rumah } \\
\text { warga-warga, ada } \\
\text { rumah panggung dan } \\
\text { ada juga rumah batu. }\end{array}$ \\
\hline
\end{tabular}


Table 2. Hasil Analisis Karangan Subjek 02

\begin{tabular}{|l|l|l|l|l|}
\hline No. & $\begin{array}{l}\text { Kode } \\
\text { Kesalahan }\end{array}$ & \multicolumn{1}{|c|}{ Kalimat } & \multicolumn{1}{|c|}{$\begin{array}{c}\text { Penjelasan } \\
\text { Kesalahan }\end{array}$} & Alternatif Perbaikan \\
\hline 1 & KPTK & $\begin{array}{l}\text { Waktu itu kami menulis } \\
\text { memakai pensil atau } \\
\text { pulpen, }\end{array}$ & $\begin{array}{l}\text { Tanda titik setelah } \\
\text { kata pulpen karena } \\
\text { akhir kalimat } \\
\text { pernyataan. }\end{array}$ & $\begin{array}{l}\text { Waktu itu kami } \\
\text { menulis memakai } \\
\text { pensil atau pulpen. }\end{array}$ \\
\hline 2 & KPTH & $\begin{array}{l}\text { Menggunakan tanda } \\
\text { belajar bersungguh } \\
\text { sungguh. }\end{array}$ & $\begin{array}{l}\text { hubung pada kata } \\
\text { bersungguh sungguh } \\
\text { untuk menyambung } \\
\text { unsur kata ulang. }\end{array}$ & $\begin{array}{l}\text { belajar bersungguh- } \\
\text { sungguh. }\end{array}$ \\
\hline 3 & KPTH & $\begin{array}{l}\text { Kami di } \\
\text { suruh membuat } \\
\text { karangan tentang } \\
\text { sebuah pekerjaan di } \\
\text { rumah. }\end{array}$ & $\begin{array}{l}\text { Menggunakan tanda } \\
\text { hubung setelah kata } \\
\text { di untuk menandai } \\
\text { bagian kata yang } \\
\text { terpenggal oleh } \\
\text { pergantian baris. }\end{array}$ & $\begin{array}{l}\text { Kami di- } \\
\text { suruh membuat } \\
\text { karangan tentang } \\
\text { sebuah pekerjaan di } \\
\text { rumah. }\end{array}$ \\
\hline 4 & $\begin{array}{l}\text { KPTK dan } \\
\text { KPTT }\end{array}$ & $\begin{array}{l}\text { Kami ada cerita untuk } \\
\text { guru dengan membuat } \\
\text { puisi kisah guru yang } \\
\text { membuat kami } \\
\text { tersenyum }\end{array}$ & $\begin{array}{l}\text { Menggunakan tanda } \\
\text { koma setelah kata } \\
\text { puisi karena adanya } \\
\text { keterangan } \\
\text { tambahan. Tanda } \\
\text { titik setelah kata } \\
\text { tersenyum karena } \\
\text { akhir kalimat } \\
\text { pernyataan. }\end{array}$ & $\begin{array}{l}\text { Kami ada cerita untuk } \\
\text { guru dengan } \\
\text { membuat puisi, kisah } \\
\text { guru yang membuat } \\
\text { kami tersenyum. }\end{array}$ \\
\hline
\end{tabular}

Table 3. Hasil Analisis Karangan Subjek 03

\begin{tabular}{|l|l|l|l|l|}
\hline No. & $\begin{array}{l}\text { Kode } \\
\text { Kesalahan }\end{array}$ & \multicolumn{1}{|c|}{ Kalimat } & \multicolumn{1}{c|}{$\begin{array}{l}\text { Penjelasan } \\
\text { Kesalahan }\end{array}$} & Alternatif Perbaikan \\
\hline 1 & KPTT & $\begin{array}{l}\text { Saya juga mau menanam } \\
\text { bungga-bungga yang } \\
\text { sangat cantik dan saya } \\
\text { melihat rumah-rumah } \\
\text { pangung, tempat motor } \\
\text { dan lain-lainya }\end{array}$ & $\begin{array}{l}\text { Menggunakan tanda } \\
\text { titik setelah kata } \\
\text { lain-lainnya karena } \\
\text { akhir kalimat } \\
\text { pernyataan. }\end{array}$ & $\begin{array}{l}\text { Saya juga mau } \\
\text { menanam bunga- } \\
\text { bunga yang sangat } \\
\text { cantik dan saya } \\
\text { melihat rumah-rumah } \\
\text { panggung, tempat } \\
\text { motor, dan lain- } \\
\text { lainya. }\end{array}$ \\
\hline 2 & $\begin{array}{l}\text { KPTK dan } \\
\text { KPTT }\end{array}$ & $\begin{array}{l}\text { Aku lihat juga kolam } \\
\text { ikan, air terjung dan } \\
\text { pingirnya, bugga-bugga, } \\
\text { ada juga kanting di } \\
\text { belakan, ada sebuah wc }\end{array}$ & $\begin{array}{l}\text { Menggunakan tanda } \\
\text { koma setelah kata } \\
\text { sebuah } w c \text { karena } \\
\text { unsur pemerincian } \\
\text { dan tanda titik }\end{array}$ & $\begin{array}{l}\text { Aku lihat juga kolam } \\
\text { ikan, air terjun dan } \\
\text { pinggirnya, bunga- } \\
\text { bunga, ada juga } \\
\text { kantin di belakang, }\end{array}$ \\
\hline
\end{tabular}




\begin{tabular}{|c|c|c|c|c|}
\hline & & dan lain-lainnya & $\begin{array}{l}\text { setelah kata lain- } \\
\text { lainnya karena akhir } \\
\text { kalimat pernyataan. }\end{array}$ & $\begin{array}{l}\text { ada sebuah wc, dan } \\
\text { lain-lainnya. }\end{array}$ \\
\hline 3 & KPTK & $\begin{array}{l}\text { Selain itu ada juga } \\
\text { penjual nasi kuning, } \\
\text { tempat bendera merah } \\
\text { putih rak buku, rak } \\
\text { sepatu dan lain-lainnya. }\end{array}$ & $\begin{array}{l}\text { Menggunakan tanda } \\
\text { koma setelah kata } \\
\text { bendera merah putih } \\
\text { dan rak sepatu } \\
\text { karena merupakan } \\
\text { unsur pemerincian. }\end{array}$ & $\begin{array}{l}\text { Selain itu ada juga } \\
\text { penjual nasi kuning, } \\
\text { tempat bendera } \\
\text { merah putih, rak } \\
\text { buku, rak sepatu, dan } \\
\text { lain-lainnya. }\end{array}$ \\
\hline 4 & KPTK & $\begin{array}{l}\text {..., motor, mobil, sepeda, } \\
\text { bentor dan di sana ada } \\
\text { mesjid tempat } \\
\text { sembahyan. }\end{array}$ & $\begin{array}{l}\text { Menggunakan tanda } \\
\text { koma setelah kata } \\
\text { bentor karena unsur } \\
\text { suatu pemerincian } \\
\text { dan tanda koma } \\
\text { setelah kata masjid } \\
\text { karena ada unsur } \\
\text { tambahan. }\end{array}$ & $\begin{array}{l}\text {..., motor, mobil, } \\
\text { sepeda, bentor, dan di } \\
\text { sana ada masjid, } \\
\text { tempat sembahyang. }\end{array}$ \\
\hline
\end{tabular}

Table 4. Hasil Analisis Karangan Subjek 04

\begin{tabular}{|l|l|l|l|l|}
\hline No. & $\begin{array}{c}\text { Kode } \\
\text { Kesalahan }\end{array}$ & \multicolumn{1}{|c|}{ Kalimat } & \multicolumn{1}{|c|}{$\begin{array}{c}\text { Penjelasan } \\
\text { Kesalahan }\end{array}$} & \multicolumn{1}{|c|}{ Alternatif Perbaikan } \\
\hline 1 & KPTK & $\begin{array}{l}\text { Sekolah saya terletak di } \\
\text { desa Banggae, }\end{array}$ & $\begin{array}{l}\text { Tanda titik setelah } \\
\text { kata Desa Banggae } \\
\text { karena akhir kalimat } \\
\text { pernyataan. }\end{array}$ & $\begin{array}{l}\text { Sekolah saya terletak } \\
\text { di Desa Banggae. }\end{array}$ \\
\hline 2 & KPTK & $\begin{array}{l}\text { Saat masuk ke sekolah } \\
\text { saya melihat banyak } \\
\text { ruangan, terutama } \\
\text { ruang kepala sekolah } \\
\text { yang cantik dan bersih } \\
\ldots . .\end{array}$ & $\begin{array}{l}\text { Menggunakan tanda } \\
\text { koma setelah kata } \\
\text { sekolah untuk } \\
\text { menghindari salah } \\
\text { baca di belakang } \\
\text { keterangan pada } \\
\text { awal kalimat. }\end{array}$ & $\begin{array}{l}\text { Saat masuk ke } \\
\text { sekolah, saya melihat } \\
\text { banyak ruangan, } \\
\text { terutama ruang } \\
\text { kepala sekolah yang } \\
\text { cantik dan bersih ..... }\end{array}$ \\
\hline 3 & KPTK & $\begin{array}{l}\text { Di dekat lapangan } \\
\text { upacara juga ada kolam } \\
\text { yaitu kolam ikan yang } \\
\text { juga ada ikan-ikannya. }\end{array}$ & $\begin{array}{l}\text { Menggunakan tanda } \\
\text { koma setelah kata } \\
\text { kolam } \text { karena } \\
\text { adanya keterangan } \\
\text { tambahan. }\end{array}$ & $\begin{array}{l}\text { Di dekat lapangan } \\
\text { upacara juga ada } \\
\text { kolam, yaitu kolam } \\
\text { ikan yang juga ada } \\
\text { ikan-ikannya. }\end{array}$ \\
\hline 4 & KPTT & $\begin{array}{l}\text { Semua kelas terlihat } \\
\text { sangat bersih. Karena } \\
\text { kita tidak boleh pakai } \\
\text { sepatu masuk ke dalam } \\
\text { kelas }\end{array}$ & $\begin{array}{l}\text { Tanda koma setelah } \\
\text { kata bersih } \\
\text { seharusnya } \\
\text { dihilangkan dan } \\
\text { menggunakan tanda } \\
\text { titik setelah kata } \\
\text { kelas } \text { karena akhir } \\
\text { kalimat peryataan. }\end{array}$ & $\begin{array}{l}\text { Semua kelas terlihat } \\
\text { sangat bersih karena } \\
\text { kita tidak boleh pakai } \\
\text { sepatu. }\end{array}$ \\
\hline
\end{tabular}


Table 5. Hasil Analisis Karangan Subjek 05

\begin{tabular}{|c|c|c|c|c|}
\hline No. & $\begin{array}{c}\text { Kode } \\
\text { Kesalahan } \\
\end{array}$ & Kalimat & $\begin{array}{c}\text { Penjelasan } \\
\text { Kesalahan } \\
\end{array}$ & Alternatif Perbaikan \\
\hline 1 & KPTK & $\begin{array}{l}\text { Saya bersekolah di MIN } \\
2 \text { Takalar terletak di } \\
\text { desa Banggae. }\end{array}$ & $\begin{array}{l}\text { Menggunakan tanda } \\
\text { koma setelah kata } \\
\text { MIN } 2 \text { Takalar } \\
\text { karena adanya } \\
\text { keterangan } \\
\text { tambahan. }\end{array}$ & $\begin{array}{l}\text { Saya bersekolah di } \\
\text { MIN } 2 \text { Takalar, } \\
\text { terletak di Desa } \\
\text { Banggae. }\end{array}$ \\
\hline 2 & KPTH & $\begin{array}{l}\text { Sekolahku berada di } \\
\text { pinggir jalan poros jadi } \\
\text { banyak kendaraan yang } \\
\text { lewat lewat. }\end{array}$ & $\begin{array}{l}\text { Menggunakan tanda } \\
\text { hubung pada kata } \\
\text { lewat lewat untuk } \\
\text { menyambung unsur } \\
\text { kata ulang. }\end{array}$ & $\begin{array}{l}\text { Sekolahku berada di } \\
\text { pinggir jalan poros } \\
\text { jadi banyak } \\
\text { kendaraan yang } \\
\text { lewat-lewat. }\end{array}$ \\
\hline 3 & KPTH & $\begin{array}{l}\text { Di depan sekolahku ada } \\
\text { banyak tanaman dan } \\
\text { bunga bunga yang } \\
\text { dipagari. }\end{array}$ & $\begin{array}{l}\text { Menggunakan tanda } \\
\text { hubung pada kata } \\
\text { bunga bunga untuk } \\
\text { menyambung unsur } \\
\text { kata ulang. }\end{array}$ & $\begin{array}{l}\text { Di depan sekolahku } \\
\text { ada banyak tanaman } \\
\text { dan bunga-bunga } \\
\text { yang dipagari. }\end{array}$ \\
\hline 4 & KPTK & $\begin{array}{l}\text { Saat masuk gerbang } \\
\text { sekolah kita akan } \\
\text { melihat banyak ruangan } \\
\text { yang bertingkat ada } \\
\text { ruang kelas } 1 \text { sampai 6, } \\
\text { ruang guru, ruang } \\
\text { kepala sekolah, } \\
\text { perpustakaan, toilet, dan } \\
\text { dapur sekolah. }\end{array}$ & $\begin{array}{l}\text { Menggunakan tanda } \\
\text { koma setelah kata } \\
\text { sekolah untuk } \\
\text { menghindari salah } \\
\text { baca pada awal } \\
\text { kalimat dan } \\
\text { menggunakan tanda } \\
\text { koma setelah kata } \\
\text { bertingkat karena } \\
\text { adanya keterangan } \\
\text { tambahan. }\end{array}$ & $\begin{array}{l}\text { Saat masuk gerbang } \\
\text { sekolah, kita akan } \\
\text { melihat banyak } \\
\text { ruangan yang } \\
\text { bertingkat, ada ruang } \\
\text { kelas } 1 \text { sampai 6, } \\
\text { ruang guru, ruang } \\
\text { kepala sekolah, } \\
\text { perpustakaan, toilet, } \\
\text { dan dapur sekolah. }\end{array}$ \\
\hline 5 & KPTH & $\begin{array}{l}\text { Ada lapangan yang } \\
\text { berada ditengah tengah, } \\
\text { kolam ikan disamping, } \\
\text { panggung aksi, dan juga } \\
\text { parkiran untuk } \\
\text { kendaraan guru guru. }\end{array}$ & $\begin{array}{l}\text { Menggunakan tanda } \\
\text { hubung pada kata } \\
\text { tengah tengah dan } \\
\text { guru guru untuk } \\
\text { menyambung unsur } \\
\text { kata ulang. }\end{array}$ & $\begin{array}{l}\text { Ada lapangan yang } \\
\text { berada ditengah- } \\
\text { tengah, kolam ikan di } \\
\text { samping, panggung } \\
\text { aksi, dan juga } \\
\text { parkiran untuk } \\
\text { kendaraan guru-guru. }\end{array}$ \\
\hline
\end{tabular}

\section{Pembahasan}

Hasil wawancara menyatakan bahwa pemahaman peserta didik mengenai penggunaan tanda baca ketika menulis sudah cukup baik, dapat dilihat pada hasil tulisan peserta didik meskipun belum secara keseluruhan. Kendala yang dihadapi oleh peserta didik dalam menggunakan tanda baca ketika menulis yaitu karena terlalu lama memikirkan 
apa yang akan ditulis. Oleh karena itu, apabila waktu untuk mengerjakan hampir habis maka peserta didik terburu-buru menulis dan kurang memperhatikan lagi ejaan yang tepat, termasuk penggunaan tanda baca.

Hasil analisis menggambarkan bahwa masing-masing tulisan peserta didik mempunyai kesalahan, ada yang berbeda dan ada yang sama antara satu dengan yang lainnya. Apabila dilihat dari tulisan peserta didik, tidak ada yang menulis secara sempurna atau tidak ada kesalahan dalam menggunakan tanda baca, ada yang salah dalam menggunakan tanda baca dan ada yang menghilangkan tanda baca itu sendiri. Adapun kesalahan dalam menggunakan tanda baca karena peserta didik sering lupa dan terburuburu ketika menulis sehingga masih terjadi kesalahan, bahkan sering.

Hasil wawancara dengan narasumber dan hasil analisis tulisan peserta didik yang dilakukan oleh peneliti, mempunyai jawaban atau gambaran yang sama. Narasumber menyatakan bahwa kesalahan penggunaan tanda baca yang ada dalam karangan peserta didik yaitu kesalahan penggunaan tanda titik, kesalahan penggunaan tanda koma, dan kesalahan penggunaan tanda hubung, dapat dilihat pada tulisan peserta didik. Namun kesalahan penggunaan tanda titik koma tidak disebutkan oleh narasumber padahal juga terdapat kesalahannya dalam tulisan peserta didik, penghilangan tanda titik koma.

Kesalahan penggunaan tanda titik sering terjadi karena peserta didik tidak memberi tanda titik pada akhir kalimat pernyataan. Kesalahan penggunaan tanda koma terdapat dalam tulisan peserta didik karena menggunakan tanda koma itu sendiri pada akhir kalimat pernyataan, seharusnya menggunakan tanda titik. Selain itu, peserta didik juga tidak menggunakan tanda koma pada suatu unsur pemerincian; penghilangan tanda koma di belakang kata atau ungkapan penghubung antar kalimat yang terdapat pada awal kalimat; penghilangan tanda koma untuk mengapit keterangan tambahan; penghilangan tanda koma untuk menghindari salah baca di belakang keterangan yang terdapat pada awal kalimat. Kesalahan penggunaan tanda hubung dilakukan oleh peserta didik karena tidak menggunakan tanda hubung untuk menandai bagian kata yang terpenggal oleh pergantian baris. Selain itu, peserta didik juga tidak menggunakan tanda hubung untuk menyambung unsur kata ulang. Ini sesuai dengan hasil penelitian (Ariyanti, 2019) yang menyatakan bahwa kesalahan sesorang dalam penggunaan tanda titik dan tanda koma karena tidak memahami makna penggunaan tanda-tanda tersebut.

Kesalahan dalam penggunaan tanda titik koma yaitu karena peserta didik tidak menggunakan atau menghilangkan tanda titik koma itu sendiri. Peserta didik terlalu banyak menggunakan tanda koma dalam kalimat tersebut dan itu dapat digantikan dengan menggunakan tanda titik koma. Tanda titik koma dalam tulisan peserta didik dapat digunakan sebagai pengganti kata penghubung untuk memisahkan kalimat setara yang satu dari kalimat setara yang lain dalam kalimat majemuk. Ini sesuai dengan hasil penelitian Puspitasari (2014). 


\section{Simpulan}

Berdasarkan hasil penelitian yang telah diuraikan di atas, disimpulkan bahwa setiap peserta didik mempunyai kesalahan dalam menggunakan tanda baca, ada yang sama dan ada yang berbeda antara satu dengan yang lainnya. Berdasarkan hasil wawancara dan analisis tulisan peserta didik, ada 4 kesalahan penggunaan tanda baca yang dilakukan oleh peserta didik dalam menulis karangan, yaitu tanda titik, tanda koma, tanda hubung, dan tanda titik koma.

Kesalahan penggunaan tanda koma adalah hal yang paling sering dilakukan oleh peserta didik. Hal yang menjadi penyebab kesalahan penggunaan tanda koma yaitu karena peserta didik menghilangkan atau tidak menggunakan tanda koma di antara unsur-unsur dalam suatu pemerincian. Tidak hanya itu, peserta didik juga tidak menggunakan tanda koma untuk mengapit keterangan tambahan dan penghilangan tanda koma untuk menghindari salah baca di belakang keterangan yang terdapat pada awal kalimat.

Kesalahan penggunaan tanda titik sering terjadi karena peserta didik tidak memberi tanda titik pada akhir kalimat yang bukan pertanyaan atau seruan. Kesalahan penggunaan tanda hubung juga sering dilakukan oleh peserta didik karena tidak menggunakan tanda hubung untuk menandai bagian kata yang terpenggal oleh pergantian baris. Selain itu, peserta didik juga tidak menggunakan tanda hubung untuk menyambung unsur kata ulang. Kesalahan penggunaan tanda titik koma dilakukan karena peserta didik tidak menggunakan tanda titik koma sebagai pengganti kata penghubung untuk memisahkan kalimat setara yang satu dari kalimat setara yang lainnya dalam kalimat majemuk. Secara umum penyebab peserta didik sering melakukan kesalahan dalam penggunaan tanda baca yaitu karena lupa dan terburu-buru ketika menulis, untuk itu guru senantiasa mengulangulang dan mengingatkan peserta didik.

\section{Daftar Pustaka}

Ariyanti, Riri. (2019) Jurnal Bahasa dan Sastra," Analisis Kesalahan Penggunaan Penggunaan Tanda Baca Pada Koran Mercusuar, vol. 4 no. 4 (2019). http://jurnal.untad.ac.id/jurnal/index.php/BDS/article/download/12178/9361.

Halimah, Andi. (2013) Konsep Dasar Bahasa Indonesia Untuk Perguruan Tinggi. Makassar: Alauddin University Press.

Idris, Yossy dkk. (2014) Peningkatan Keterampilan Menulis Karangan Deskripsi Melalui Metode Discovery Dengan Menggunakan Media Gambar Mahasiswa Prodi Pendidikan Bahasa dan Sastra Indonesia TA 2011/2012 Universitas Ekasakti Padang, vol. 2 no. 3.

Karitas, Diana Puspa. (2017) Tema 5 Ekosistem: Buku Tematik Terpadu Kurikulum 2013. Balitbang: Pusat Kurikulum dan Perbukuan Kemendikbud.

Kuspitasari, Endah Septiana (2013). Analisis Kesalahan Penggunaan Tanda Baca pada Karangan Narasi Siswa Kelas VII SMP Diponegoro 8 Rowalo. Purwokerto: Prodi Pendidikan Bahasa dan Sastra Indonesia UMP.

Puspitasari, Yeti. (2014). Analisis Kesalahan Huruf Kapital dan Tanda Baca Pada Paragraf Deskriptif Siswa Kelas V SD Negeri Sampay Rumpin-Bogor. Jakarta: Fak. Ilmu Tarbiyah dan Keguruan UIN Syarif Hidayatullah.

RM, David Budianto. (2019). Analisis Kesalahan Tanda Baca dan Ejaan Yang Disempurnakan (EYD) dalam Karangan pada Pembelajaran Bahasa Indonesia 
Jurnal Onoma: Pendidikan, Bahasa dan Sastra PBSI FKIP Universitas Cokroaminoto Palopo Volume 7 Nomor 1 Tahun 2021
ISSN 2443-3667 (Print)

ISSN 2715-4564 (Online)

Siswa Kelas V di MI AL-ISLAM Kota Bengkulu. Bengkulu: Fak. Tarbiyah dan Tadris IAIN Bengkulu. 